Vol 12, Issue 7, 2019

\title{
CYTOGENETIC BIOMONITORING AND IMMUNOCYTOCHEMICAL STUDIES ON CAR SPRAY PAINTERS IN ENUGU METROPOLIS, ENUGU STATE, NIGERIA
}

\author{
ANULIKA ONYEMELUKWE*, PETER ACHUKWU, NKIRUKA AZUBUIKE, UZOAMAKA MADUAKOR, \\ OKECHUKWU ONWUKWE
}

Department of Medical Laboratory Sciences, Faculty of Health Sciences and Technology, College of Medicine, University of Nigeria, Enugu Campus, Nigeria. Email: anulika.onyemelukwe@unn.edu.ng

Received: 20 May 2019, Revised and Accepted: 14 June 2019

ABSTRACT

Objective: This study assessed the cytogenetic damage associated with occupational exposure to paints by evaluating exfoliated buccal epithelial cells from car spray painters in Enugu metropolis using some biological markers.

Methods: A total of 352 apparently healthy males, comprising 200 car spray painters and a control group of 152 individuals, participated in the study. Buccal smears were obtained from each participant and were stained using hematoxylin and eosin technique. A total of 1000 cells per individual were scored under light microscopy to determine the frequencies of micronuclei (MN) and binucleate cells (BNC). Structured questionnaires were used to obtain relevant participant information. Expression patterns of Ki-67and p53 genes on the buccal cells were determined by immunocytochemical methods.

Results: Car spray painters had significantly increased frequencies of MN and BNC $\left({ }^{*} \mathrm{p}<0.05\right)$ when compared to the control subjects. Paint sprayers aged over 35 years had higher buccal cell MN frequency when compared to those $<25$ years. Furthermore, car spray painters who have worked for $\geq 15$ years had higher frequencies of MN when compared to those who had worked for $<5$ years $\left({ }^{*} \mathrm{p}<0.05\right)$. Smoking and alcohol consumption increased the MN frequency of the car spray painters $\left({ }^{*} \mathrm{p}<0.05\right)$. There was no expression of p53 and Ki-67 genes in the buccal cells of both control and exposed subjects.

Conclusion: Car spray painters in Enugu metropolis may be occupationally exposed to substances capable of inducing genotoxic changes which manifested as increased frequency of MN in their buccal cells.

Keywords: Micronuclei, Binucleate cells, Buccal cell, Occupational exposure, Car spray painters, Immunocytochemical, Genotoxicity.

(C) 2019 The Authors. Published by Innovare Academic Sciences Pvt Ltd. This is an open access article under the CC BY license (http://creativecommons. org/licenses/by/4. 0/) DOI: http://dx.doi.org/10.22159/ajpcr.2019.v12i7.34226

\section{INTRODUCTION}

Painting is an age-long profession. Painters are often occupationally exposed to substances in paints (such as solvents and metals) which may be deleterious to their health due to chronic poisoning [1,2]. Paints are a mixture of solvents, pigments, organic compounds, and other additives. Most of these compounds are volatile and easily spread into the environments as paint mists during spraying activities [3]. Different paints of varying chemistry have been in use for both domestic and industrial purposes. Paints and its constituents such as organic solvents, including aromatic hydrocarbons (mainly toluene), aliphatic hydrocarbons, alcohols, ketone and esters, and metals such as aluminum, cobalt, chromium, titanium, and lead may cause unfavorable cellular effects to occupationally exposed individuals [4,5]. Despite the fact that the International Agency for Research on Cancer has not considered some of these compounds contained in paints as being carcinogenic, some individual metals or their mixture may contribute to an increased risk of cancer in exposed individuals hence the classification of paints as a Group 1 carcinogen [6-8]. Furthermore, exposure to these organic solvents, metals, and other potentially mutagenic compounds in paints (such as phthalic acids and chlorophenols) is known to be capable of inducing DNA damage and chromosomal changes sometimes manifesting as micronucleus $[1,9]$.

The examination of exfoliated buccal epithelial cells using the buccal cell micronuclei (MN) test as a biomarker serves as a minimally invasive method for bio-monitoring of human exposure to potentially genotoxic environmental pollutants [5]. In experimental animal models, MN assay has also been employed to monitor the damage of chromatin materials caused by exposure of animals to chemicals. A previous study documented an increase in the percentage frequency of micronucleus in animals treated with arsenite, which indicates chromosomal damage [10]. Another study also employed the in vivo micronucleus assay in bone marrow cells of male and female Sprague-Dawley rats to evaluate genotoxicity [11]. MN are extra-nuclear bodies that contain damaged chromosome fragments and/or whole chromosomes that were not incorporated into the nucleus after cell division [12]. An increased number of MN in exfoliated buccal cells is often an indication of genetic damage [13]. The presence of MN can be seen as an early warning sign for the potential risk of developing longterm health problems [14]

Car spray workers in Enugu metropolis, Nigeria constitute a major workforce with a considerable population. In the course of their work, these painters are exposed to paint mist or vapor primarily through inhalation, dermal absorption, and ingestion [15]. Mishandling of paints, inhalation of paint materials, and inadequate use of personal protective equipment (PPE) observed among some car spray painters have increased their risk of exposure to these harmful chemicals which are potential threats to health [16]. In view of this, the present study was, therefore, designed to evaluate cytogenetic damage of exfoliated cells of the buccal mucosa of car spray painters by determination of MN frequency using the MN test and binucleated cells.

\section{METHODS}

Ethical consideration

Approval for the study was obtained from the Health Research and Ethics Committee of the University of Nigeria Teaching Hospital Ituku-Ozalla, 
with approval number:-(NHREC/05/01/2008B-FWA000024581RB00002323). Before recruitment, the details of procedures involved in the study were explained to the study participants, volunteers who consented to participate in the study signed an informed consent form.

\section{Study area and design}

The study was conducted in Enugu, the capital city of Enugu state, Nigeria, and lasted for 6 months from June 2018 to December 2018. The study adopted a cross-sectional design.

\section{Study participants}

The study participants were adult males between the ages of 18 and 65 years, recruited from Enugu metropolis, South East, Nigeria. A total of 352 individuals participated in the study, 200 of the participants were car spray painters directly exposed to paints while the other 152 neither worked as car spray painters nor were exposed to paints and served as control. A structured questionnaire was used to obtain information such as age, smoking habit, alcohol consumption, exposure to radiation, and occupational exposure characteristics of the selected participants.

\section{Inclusion criteria}

Adult males between the ages of 18 and 65 years, who were apparently healthy with no oral lesion that has worked as car spray painters for at least 6 months and consented to participate in the study.

\section{Exclusion criteria}

Individuals outside the age range of 18-65 years, those with oral lesions and had been exposed to X-ray radiations in the past 1 year and non-consenting individuals were excluded from the study.

\section{Sample collection, staining, and evaluation}

Before sample collection, the participating individuals thoroughly rinsed their mouth with water to remove any unwanted debris. Buccal cells were obtained by scrapping the inside of both cheeks gently with a sterile wooden spatula; the sample was suspended in a labeled universal container containing $95 \%$ ethanol which served as a fixative. The samples were prepared in a laboratory by transferring into centrifuge bottles and centrifuging at $5000 \mathrm{rpm}$ for $5 \mathrm{~min}$, the supernatants were decanted, and the sediments were smeared on poly-L-lysine charged grease free slides. They were allowed to air dry and stained with hematoxylin and eosin staining technique and then examined using a light microscope at $\times 40$ magnification to identify and record the number of buccal cells with MN and BNC. At least 1000 intact buccal epithelial cells per individual were examined and scored using the criteria described by Tolbert et al. [17] and the MN and BNC frequencies recorded. MN were counted by two independent observers who evaluated the slides twice at different intervals to minimize intra- and inter-observer bias.

\section{Immunocytochemical (ICC) staining and evaluation for p53 and Ki-67}

ICC staining of buccal smears was carried out according to previously described methods [18,19]. Monoclonal antibodies Ki-67 and p53 were employed. Expose Mouse and Rabbit Specific Horseradish Peroxidase/Diaminobenzidine detection immunohistochemistry kit was employed for immunostaining while detection of immunoreactivity was performed according to the manufacturer's instruction.

\section{Procedure}

Smears were hydrated by passing through $50 \%$ ethanol for $15 \mathrm{~s}$ and then to distilled water for $15 \mathrm{~s}$. Slides were arranged in slide racks and treated in protein block and biotin block solutions for $25 \mathrm{~min}$ in each solution. Thereafter, they were arranged on a staining rack and flooded with phosphate buffer saline (PBS) solution to prevent drying. The smears were drained afterward, the exact portions of smears on slides were carefully ringed with a hydrophobic pen, and diluted antibodies (1:100) (anti-Ki-67 and p53) were applied onto smears with the aid of Pasteur pipette and allowed to incubate at room temperature for $1 \mathrm{~h}$. After incubation in the primary antibodies, the smears were washed with PBS, flooded with a secondary antibody for $25 \mathrm{~min}$, washed with PBS, drained and diaminobenzidine DAB were applied for $5 \mathrm{~min}$. Finally, the smears were washed with PBS; counterstained in Harris Hematoxylin for $5 \mathrm{~min}$, washed in water and was differentiated by dipping 10 times in $1 \%$ acid alcohol. Slides were later washed and blued in tap water, dehydrated by passing through $70 \%, 90 \%$ and two changes of absolute ethyl alcohol for $15 \mathrm{~s}$ each, cleared in xylene and mounted in DPX. Ki-67 and p53 positive immune control sections were also stained alongside test and control smears. The ICC staining was semi-quantitatively scored, according to Zlobec et al. [18].

\section{Statistical analysis}

Statistical analysis was performed using Statistical Package for the Social Sciences version 20.0. Data obtained from the assay were expressed as the mean \pm standard deviations. Student's t-test (two-tailed) was used to compare nuclear abnormalities among test and control groups. The level of significance was set at ${ }^{*} \mathrm{p}<0.05$. Overall effects of age, exposure duration, alcohol consumption, and smoking were determined using one-way analysis of variance, followed by post-hoc multiple comparisons.

\section{RESULTS}

\section{Effects of exposure on buccal cell nuclei}

Nuclear damage indices assessed in the buccal cells of study participants were MN and BNC. (Fig. 1a-b) is representative micrographs showing normal buccal cells (Fig. 1a); cells with MN (Fig. 1b) and BNC (Fig. 1c).

Table 1 compared the mean values of the frequencies of MN and BNC in control and exposed car spray painters. Car spray painters were found to have significantly higher MN $(p=0.000)$ and BNC $(p=0.000)$ when compared to the control subjects.

Variations of nuclear abnormalities (MN and BNC) based on demographics, lifestyle, and exposure characteristics

Car spray painters were further subdivided according to age, occupational exposure factors, and lifestyle to assess the influence of these factors on the frequency of MN and BNC (Table 2). With respect to age, the result showed a statistically significant increase in the MN of car spray painters in the age group $>35$ years when compared with those in the lower age groups $<25$ years and $26-35$ years.

Car spray painters who have worked for 5-10 years, 11-15 years, and $>15$ years had significantly higher $\mathrm{MN}(\mathrm{p}=0.000)$ when compared with those who have worked for $<5$ years. Duration of exposure and use of PPE did not significantly affect the distribution of MN and BNC, though cars spray painters who worked $>10 \mathrm{~h}$ daily had an increased frequency of MN and BNC though not statistically significant. Cigarette smoking and alcohol consumption significantly increased MN frequency $(\mathrm{p}=0.000)$ of car spray painters.

\section{Effects of exposure on immunoreactivities for $\mathrm{p} 53$ gene}

Buccal cell cytology of both car spray painters and controls participants was negative for $\mathrm{p} 53$ immunoreactivities (Fig. $2 \mathrm{a}$ and b). The positive stain immune control section, however, showed p53 reactivity indicated using arrows (Fig. 2c).

\section{Effects of exposure on immunoreactivities for Ki-67 gene}

There was also no expression of Ki-67 in the buccal cell nuclei of both car spray painters and control participants (Fig. $3 a$ and b). The positive stain immune control section shows expression of Ki-67 (Fig. 3c).

\section{DISCUSSION}

Occupational and environmental exposure to hazardous chemical agents poses a great risk to human health and has become a global concern $[20,21]$. Buccal epithelial cells are often the first to come in contact with airborne pollutants in occupationally exposed individuals, especially when exposure is through inhalation or ingestion. These cells are capable of metabolizing proximate carcinogens into reactive products [22]. 

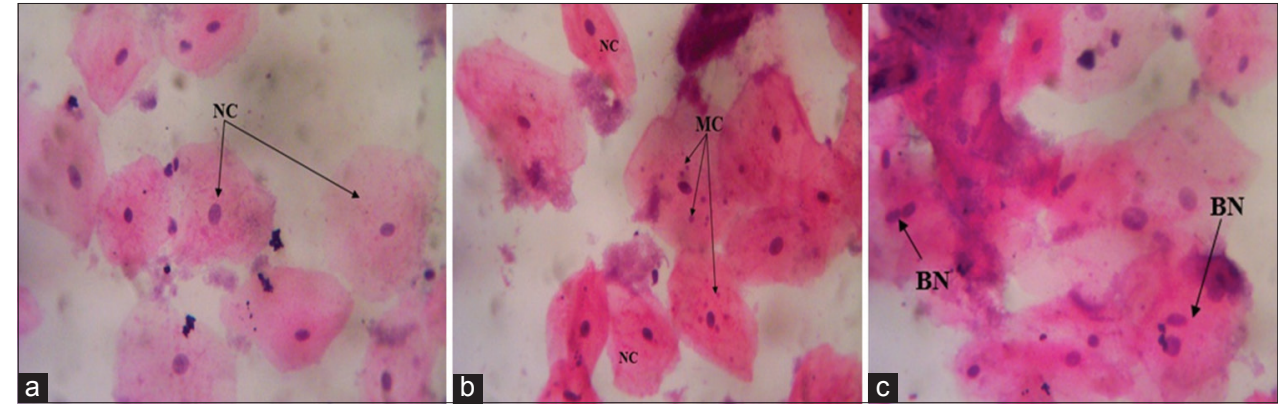

Fig. 1: Light photomicrographs of exfoliated buccal epithelial cells of: (a) Unexposed control subject showing normal cells (NC);

(b) car spray painter showing presence of $\mathrm{NC}$ and $\mathrm{MN}$ cells (MN); and (c) car spray painter showing binucleated cells (BN)

(Stain: H\&E/Mag: ×400)

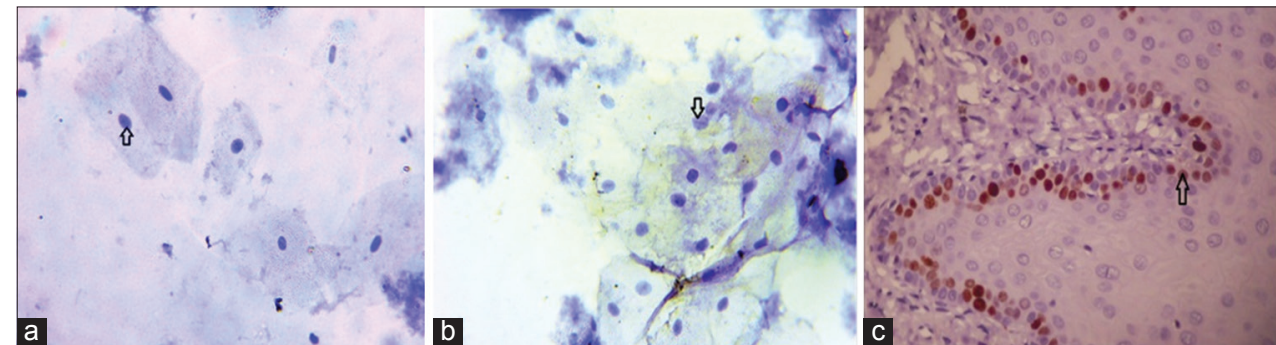

Fig. 2: P53 photomicrographs showing negatively stained nuclei (arrows) in (a) car spray painters and (b) control subject. The positive immune control section (c) showing positively stained nucleus (arrow). (Mag: ×400)

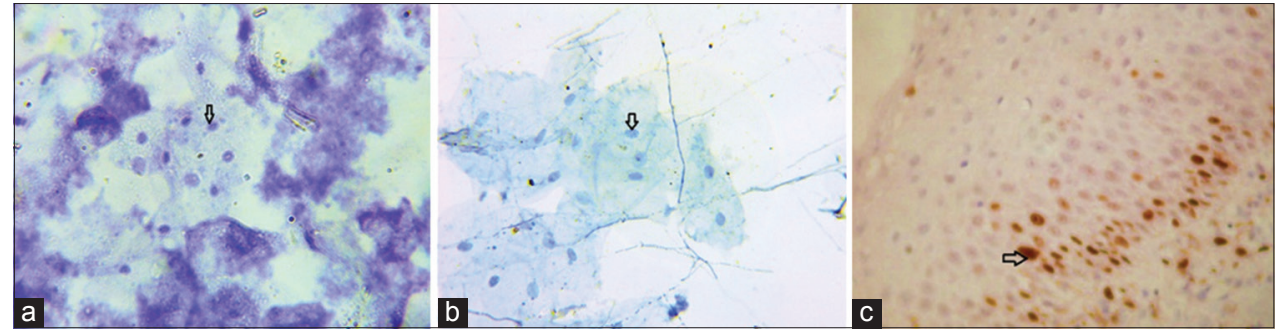

Fig. 3: Ki-67 photomicrographs showing negatively stained nuclei (arrows) in (a) car spray painter and (b) control subject. The positive immune control section (c) shows a positively stained nucleus (arrow) (Mag: ×400)

In the present study, both car spray painters and the unexposed control group had MN and BNC in their exfoliated buccal epithelial cells. However, the car spray painters had significantly higher frequencies of buccal cell MN and BNC when compared to the unexposed control subjects. The result obtained from the present study corroborates with the findings of a preliminary study conducted on automobile spray painters in the coal camp mechanic village in Enugu [23]. More so, previous studies have documented similar increased levels of MN and other nuclear abnormalities in buccal epithelial cells of workers occupationally exposed to potentially genotoxic substances [9,24-26]

With reference to age, the result showed that car spray painters older than 35 years had the highest frequency of MN and BNC. Furthermore, there was a significantly higher MN frequency in the buccal cells of car spray painters who were older than 35 years when compared to those $<35$ years. This finding suggests that there may be an association between an individual's age and the frequency of MN, as previously documented [26]. In line with this finding, a previous study also reported a significant change in MN frequency due to age in a study involving automobile painters in South India [27]. In contrast; however, a previous study reported no significant change in MN frequency in relation to age among gas station attendants [16].

In the present study, a greater percentage of the exposed participants spent 5-10 h daily in their workplace, this may have also attributed to the significantly higher frequency of MN among those that have worked as car spray painters for 5-10 years, 11-15 years, and above 15 years when compared to those who have worked for $<5$ years. This suggests a positive correlation between the increased MN frequency and the number of years of exposure/frequency of exposure which is similar to the findings documented by a previous study which showed an increased MN frequency with a positive correlation with increased period of exposure in motor garage workers [2]. Car spray painters who have worked for more than 15 years had a higher frequency of BNC when compared to those who have worked for $<5$ years. Even though the finding was not significant, it is of importance because an increase in BNC frequency of BNC is considered as an indicator of cytotoxicity [1].

The use of PPE such as goggles, overalls, gloves, and boots did not significantly alter the frequency of MN and BNC in car spray painters even though most of the workers sampled in this study did not strictly adhere to an adequate use of PPE while working. A previous study in Nigeria documented that only a few paint workers use some form of PPE despite public awareness on the use of PPE [2]. Regardless, adequate use of PPE among car spray painters is essential in preventing health hazards associated with occupational exposure.

According to previous studies [22,28], lifestyle factors such as alcohol consumption and smoking habits are considered as contributing factors for increased frequency of nuclear abnormalities in individuals who are exposed to genotoxic substances. The present study showed that alcohol consumption in addition to cigarette smoking habits 
Table 1: A comparison of $\mathrm{MN}$ and $\mathrm{BNC}$ frequencies in control subjects and car spray painters

\begin{tabular}{lll}
\hline \multirow{2}{*}{ Groups } & \multicolumn{2}{l}{ Parameters (Mean \pm SD) } \\
\cline { 2 - 3 } & MN & BNC \\
\hline Control & $12.14 \pm 0.61$ & $1.45 \pm 0.11$ \\
Car spray painters & $53.56 \pm 0.67^{*}$ & $4.95 \pm 0.11^{*}$ \\
p-value & 0.000 & 0.000 \\
\hline Data expressed as mean $\pm S D{ }^{*}{ }^{*}<0.05$ when compared with control. MN cells;
\end{tabular}

BNC: Binucleated cells, MN: Micronuclei, SD: Standard deviations

Table 2: Frequency of MN and BNC in car spray painters and by demographics and exposure variables

\begin{tabular}{|c|c|c|c|}
\hline \multirow[t]{2}{*}{ Characteristics } & \multicolumn{3}{|c|}{ Nuclear abnormalities } \\
\hline & $\mathbf{n}$ & MN & BMC \\
\hline \multicolumn{4}{|l|}{ Age (years) } \\
\hline$<25$ & 22 & $48.82 \pm 2.44$ & $5.00 \pm 0.44$ \\
\hline $26-35$ & 142 & $52.87 \pm 0.70$ & $4.92 \pm 0.12$ \\
\hline$>35$ & 36 & $59.17 \pm 1.76^{*}$ & $5.06 \pm 0.11$ \\
\hline p-value & & 0.000 & 0.880 \\
\hline \multicolumn{4}{|l|}{ Working experience (\%) } \\
\hline$<5$ & 13 & $42.69 \pm 3.43$ & $4.15 \pm 0.42$ \\
\hline $5-10$ & 153 & $52.41 \pm 0.64^{*}$ & $5.10 \pm 0.12$ \\
\hline $11-15$ & 27 & $62.22 \pm 1.30^{*}$ & $4.37 \pm 0.30$ \\
\hline$>15$ & 7 & $65.57 \pm 3.98^{*}$ & $5.29 \pm 0.57$ \\
\hline p-value & & 0.000 & 0.228 \\
\hline \multicolumn{4}{|l|}{ Duration of exposure (daily) } \\
\hline $5-10 \mathrm{~h}$ & 185 & $17.40 \pm 0.23$ & $5.10 \pm 0.18$ \\
\hline$>10 \mathrm{~h}$ & 15 & $17.82 \pm 0.69$ & $5.90 \pm 0.56$ \\
\hline p-value & & 0.402 & 0.373 \\
\hline \multicolumn{4}{|l|}{ Use of protective equipment } \\
\hline Yes & 85 & $52.86 \pm 10.16$ & $5.00 \pm 1.69$ \\
\hline No & 115 & $54.08 \pm 9.06$ & $4.91 \pm 1.45$ \\
\hline p-value & & 0.604 & 0.207 \\
\hline \multicolumn{4}{|c|}{ Lifestyle habits (smoking and alcohol consumption) } \\
\hline Nonsmokers+non drinkers & 66 & $51.00 \pm 1.21$ & $4.71 \pm 0.20$ \\
\hline Smokers only & 9 & $56.33 \pm 2.34$ & $5.11 \pm 0.63$ \\
\hline Drinkers only & 100 & $53.11 \pm 0.88$ & $5.08 \pm 0.14$ \\
\hline Smokers+drinkers & 25 & $61.12 \pm 1.72 *$ & $5.00 \pm 0.34$ \\
\hline p-value & & 0.000 & 0.503 \\
\hline
\end{tabular}

${ }^{*} \mathrm{p}<0.05, \mathrm{~N}$ : Number, MN: Micronuclei, BNC: Binucleate cells

significantly increased the frequency of $\mathrm{MN}$ in exposed car spray painters when compared to car spray painters that neither smoked cigarette nor consumed alcohol. This may be attributed to benzene, which is used in the production of paints and also a content of cigarette smoke [1]. Previous epidemiological studies showed a clear relationship between increase in $\mathrm{MN}$ frequency and exposure to benzene and its metabolites [29,30], cigarette smoking is one of the factors that may influence the rate of cytogenetic damage, such as MN in humans[31]. Alcoholic beverages have been described as containing mutagenic substances [32]. Similar to this finding, a previous study also documented an increase in MN frequency in buccal cells of motor garage workers who consumed alcohol [33]. Another study showed a direct relationship between buccal mucosa nuclear changes and cigarette smoking and alcohol beverage consumption [34].

The expression of tumor suppressor gene; p53 and cell proliferation marker; Ki-67 has been widely used to monitor the progression of epithelial dysplasia of the oral cavity [35]. There was no expression of both p53 and Ki-67 genes in the buccal epithelial cells of car spray painters and control subjects. However, there was significantly increased MN frequency in the epithelial buccal cells of car spray painters in the present study, moreso, a previous study reported that increased MN frequency in peripheral blood lymphocytes of healthy subjects is a predictive biomarker of cancer risk, 12-15 years after the MN test was peformed [36]. Another study documented a gradual increase in $\mathrm{MN}$ frequency of exfoliated buccal cells from normal mucosa to precancerous lesions then to oral squamous carcinoma, which suggested a link of this biomarker with neoplastic progression [37]. With the observed increase of MN frequency in buccal epithelial cells of car spray painters in the present study, periodical biological monitoring of these exposed car painters is therefore needful. Similar to our findings, a previous study on ICC staining for p53 and Ki-67 to characterize urothelial cells in urine cytology revealed a negative immunoreactivity for p53 and Ki-67 genes in subjects with normal cytology with median percentage values (first to third quartile) of p53 and Ki-67 being $0(0-5)$ and $0(0-1)$, respectively. The authors, however, recorded positive immunoreactivities for p53 and Ki-67 genes in subjects with urothelial carcinoma for 30 (10-80) and 20 (10-30), respectively [38].

\section{CONCLUSION}

The results obtained from the present study showed that car spray paint workers in Enugu metropolis occupationally exposed to genotoxins have increased $\mathrm{MN}$ and BNC frequencies, which may pose potential health risks with fatal consequences. There is, therefore, need to provide appropriate training for workers on the importance of using PPE and other safety practices so as to reduce the exposure to genotoxic agents and improve conditions of occupational safety.

\section{ACKNOWLEDGMENT}

The authors wish to thank the members of the teaching laboratory of the Department of Medical Laboratory Science, University of Nigeria Enugu Campus for the technical support and all the volunteers of this study for their maximum cooperation.

\section{AUTHOR'S CONTRIBUTIONS}

Anulika Onyemelukwe - conducted the study and drafted the manuscript, Peter Achukwu - designed and supervised the study, Nkiruka Azubuike - performed the statistical analysis, Uzoamaka Madakor - assisted in laboratory investigations, and Okechukwu Onwukwe - critically reviewed the manuscript. All authors read and approved the final manuscript.

\section{CONFLICTS OF INTEREST}

The authors declare that there are no conflicts of interest for this research.

\section{REFERENCES}

1. Cassini C, Calloni C, Bortolini G, Garcia SC, Dornelles MA Henriques JA, et al. Occupational risk assessment of oxidative stress and genotoxicity in workers exposed to paints during a working week. Int J Occup Med Environ Health 2011;24:308-19.

2. Awodele O, Popoola TD, Ogbudu BS, Akinyede A, Coker HA, Akintonwa A, et al. Occupational hazards and safety measures amongst the paint factory workers in Lagos, Nigeria. Saf Health Work 2014;5:106-11

3. Shastri NM, Pant H. Genotoxic profile of motor garage workers. Am J Infect Dis 2011;7:55-60.

4. Pinto D, Ceballos JM, García G, Guzmán P, Del Razo LM, Vera E, et al. Increased cytogenetic damage in outdoor painters. Mutat Res 2000;467:105-11.

5. Lee $\mathrm{KH}$, Ichiba M, Zhang J, Tomokuni $\mathrm{K}$, Hong $\mathrm{YC}$, Ha M, et al. Multiple biomarkers study in painters in a shipyard in Korea. Mutat Res 2003;540:89-98

6. IARC. Inorganic and Organic Lead Compounds. Monograph on the Evaluation of the Carcinogenic Risk of Chemicals to Humans. Geneva: IARC Press; 2007

7. Scélo G, Metayer C, Zhang L, Wiemels JL, Aldrich MC, Selvin S, et al. Household exposure to paint and petroleum solvents, chromosomal translocations, and the risk of childhood leukemia. Environ Health Perspect 2009;117:133-9.

8. IARC. Working Group on the Evaluation of Carcinogenic Risks to Humans. Some organic solvents, resin monomers and related compounds, pigments and occupational exposures in paint manufacture and painting. IARC Monogr Eval Carcinog Risks Hum 1989;47:1-442.

9. Diaz S, Fonseca G, Fernandez I. Analysis of lymphocyte and oral 
mucosa cell micronuclei in Cuban paint industry workers. Hereditas 1990;113:77-80.

10. Ambasta SK, Kumari S, Sinha UK. Anticlastogenicity of Tinospora cordifolia stem extract against arsenic genotoxicity in Mus musculus bone marrow erythrocytes using micronucleus assay. Int J Pharm Pharm Sci 2017;9:260-4

11. El Makawy IA, Ashraf AN, Alaa B. Potential genotoxicity and histopathological alteration evaluation of Heptex ${ }^{\circledR}$. Int J Pharm Pharm Sci 2015;7:300-6.

12. Luzhna L, Kathiria P, Kovalchuk O. Micronuclei in genotoxicity assessment: From genetics to epigenetics and beyond. Front Genet 2013;4:131.

13. Banerjee S, Singh NN, Sreedhar G, Mukherjee S. Analysis of the genotoxic effects of mobile phone radiation using buccal micronucleus assay: A Comparative evaluation. J Clin Diagn Res 2016;10:ZC82-5.

14. Au WW. Cytogenetic assays in monitoring human exposure and prediction of risk. Environ Mutagen Carcinog Terat 1991;23:236-45.

15. Benites CI, Amado LL, Vianna RA, Martino-Roth Mda G. Micronucleus test on gas station attendants. Genet Mol Res 2006;5:45-54

16. Mersal FA, Esmat OM. Structured teaching program on occupational health hazards among painting workers at elherafeyien city in Cairo. Biomed Nurs 2018;4:1-11

17. Tolbert PE, Shy CM, Allen JW. Micronuclei and other nuclear anomalies in buccal smears: Methods development. Mutat Res 1992;271:69-77.

18. Zlobec I, Steele R, Michel RP, Compton CC, Lugli A, Jass JR, et al., Scoring of p53, VEGF, bcl-2 and APAF-1 immunohistochemistry and interobserver reliability in colorectal cancer. Mod Pathol 2006;19:1236-42.

19. Humayun S, Prasad VR. Expression of p53 protein and ki-67 antigen in oral premalignant lesions and oral squamous cell carcinomas: An immunohistochemical study. Natl J Maxillofac Surg 2011;2:38-46.

20. Akan JC, Abdulrahman FI, Ogugbuaja VO, Ayodele JT. Heavy metals and anion levels in some samples of vegetable grown within the vicinity of Challawa industrial area, Kano state, Nigeria. Am J Appl Sci 2009;6:534-42

21. Franco SS, Nardocci AC, Günther WM. PAH biomarkers for human health risk assessment: A review of the state-of-the-art. Cad Saude Publica 2008;24 Suppl 4:s569-80.

22. Holland N, Bolognesi C, Kirsch-Volders M, Bonassi S, Zeiger E, Knasmueller S, et al. The micronucleus assay in human buccal cells as a tool for biomonitoring DNA damage: The HUMN project perspective on current status and knowledge gaps. Mutat Res 2008;659:93-108.

23. Azubuike NC, Onwukwe OS, Onyemelukwe AO, Maduakor UC, Udoh IP, Ikele IT, et al. Micronucleus evaluation of exfoliated buccal epithelial cells from automobile spray painters a preliminary study.
Anat J Afr 2019;8:1457-66.

24. Liu Q, Cao J, Liu Y, Lü YM, Qin B, Jiang B, et al. Follow-up study by chromosome aberration analysis and micronucleus assays in victims accidentally exposed to 60Co radiation. Health Phys 2010;98:885-8.

25. Singaravelu SR, Sellappa SU. Assessment of genotoxicity in exfoliated buccal epithelial cells of foundry workers occupationally exposed to polycyclic aromatic hydrocarbons. Asian J Pharm Clin Res 2013;6:339-42.

26. Sellappa S, Prathyumnan S, Joseph S, Keyan KS. Micronucleus test in exfoliated buccal cells from chromium exposed tannery workers. Int J Biosci Biochem Bioinform 2011;1:58.

27. Khan MR, Sellappa, S. Elevated frequencies of micronuclei and other nuclear abnormalities in buccal epithelial cells of spray painters in South India. Int J Pharm Life Sci 2013;4:2680-4.

28. Diler SB, Ergene S. Nuclear anomalies in the buccal cells of calcite factory workers. Genet Mol Biol 2010;33:374-8.

29. Türkel B, Egeli U. Analysis of chromosomal aberrations in shoe workers exposed long term to benzene. Occup Environ Med 1994;51:50-3.

30. Surrallés J, Autio K, Nylund L, Järventaus H, Norppa H, Veidebaum T, et al. Molecular cytogenetic analysis of buccal cells and lymphocytes from benzene-exposed workers. Carcinogenesis 1997;18:817-23.

31. Celik A, Cavaş T, Ergene-Gözükara S. Cytogenetic biomonitoring in petrol station attendants: Micronucleus test in exfoliated buccal cells. Mutagenesis 2003;18:417-21.

32. Maluf SW, Erdtmann B. Evaluation of occupational genotoxic risk in a Brazilian hospital. Genet Mol Biol 2000;23:485-8.

33. Nandan M, Shastri M, Hemlata, P, Pant S. Genotoxic profile of motor garage workers. Am J Infect Dis 2011;7:55-60.

34. Jyoti S, Siddiquea YH, Khan S. Effect on micronucleus frequency and DNA damage in buccal epiththelial cells of various factors among pan masala and gutkhaoral science. Int J Oral Sci 2015;12:9-14.

35. Angiero F, Berenzi A, Benetti A, Rossi E, Del Sordo R, Sidoni A, et al. Expression of p16, p53 and ki-67 proteins in the progression of epithelial dysplasia of the oral cavity. Anticancer Res 2008;28:2535-9.

36. Bonnasi S, Neri M, Lando C, Ceppi M, Lin Y, Chang WP, et al. Effect of smoking habit on the frequency of micronuclei in human lymphocytes: Results from human micronucleus project. Mutat Res 2003;543:155-66.

37. Casartelli G, Bonatti S, De Ferrari M, Scala M, Mereu P, Margarino G, et al. Micronucleus frequencies in exfoliated buccal cells in normal mucosa, precancerous lesions and squamous cell carcinoma. Anal Quant Cytol Histol 2000;22:486-92.

38. Courtade-Saïdi M, Aziza J, d'Aure D, Bérard E, Evrard S, Basset C, et al. Immunocytochemical staining for p53 and ki-67 helps to characterise urothelial cells in urine cytology. Cytopathology 2016;27:456-64. 